\title{
Human-Computer Interaction-Based Foreign Language Instruction
}

\author{
Chunying Zhang \\ Department of Foreign Languages and Cultures, Beijing \\ Wuzi University \\ Beijing, China \\ Zhangchunying1979@sina.com
}

\author{
Weihong Zhang \\ English Department, Hebei Tourism Vocational College \\ Chengde, China \\ mayzhwh@126.com
}

\begin{abstract}
To describe a best and effective teaching model at the higher education level, the current situation of foreign language instruction in colleges and universities in China is presented first, then the feasibility and advantages of human-computer interaction-based foreign language teaching model are elaborated. The new teaching model has an advantage over the centuries-old traditional didactic method by comparison. Well-implemented human-computer interaction is much more effective than traditional lecturebased instruction. Unlike the teacher-oriented teaching method, the new teaching model is student-centered selfdirected learning and quality-oriented education. It can create real-life situations for teachers and students and meet the different learning needs and different learning abilities of students. In addition, it can provide students more chances to learn automatically and develop creativity among them, helping them get more knowledge and the best learning effect. Therefore, it can greatly increase the student interest in learning and at the same time improve the teaching quality completely.
\end{abstract}

Keywords-human-computer interaction; universities; foreign language instruction; learner-centered approach ; teaching model

\section{INTRODUCTION}

In the modern society, computers have become commonplace in the personal as well as the professional lives. Computers have made many of the everyday tasks easier and faster and made the society more productive. [1] Although the use of network technology in teaching and learning is the latest trend in education and training, [2] it has been used widely in the colleges and universities now. Especially, since the College English Curriculum Requirements (Requirements hereafter) was unveiled in 2007, most colleges and universities paid more money for audio-visual aids and equipment to carry out the Requirements. The Requirements claimed that in view of the marked increase in student enrollments and the relatively limited resources, colleges and universities should remold the existing unitary teacher-centered pattern of language teaching by introducing computer-based and classroom-based teaching models. The new model should be built on modern information technology, particularly network technology, so that foreign language teaching and learning will be, to a certain extent, free from the constraints of time or place and geared towards students' individualized and autonomous learning [3]. HumanComputer Interaction (HCI) has been found to be one of the most potent tools for improving learning performance and the efficiency of foreign language teaching.

Definition of human-computer interaction

Thomas T. Hewett et al. defined Human-computer interaction (see Figure 1.) as "a discipline concerned with the design, evaluation, and implementation of interactive computing systems for human use and with the study of major phenomena surrounding them." [4] P. Johnson wrote that HCI is the study of the interaction between people and computers. It deals with how people and computers can effectively interact to carry out tasks, and how such interactive system is designed [5]. Thus it can be seen that HCI can enhance the application of computer programs and the ease of computer users. HCI has much to do with learning and cognition and an emerging approach to learning [6]. HCI is a learner-centered approach that puts learners in the central part of each stage of learning. It can provide learners with different tasks, offering better access to information, and creating much more powerful forms of communication.

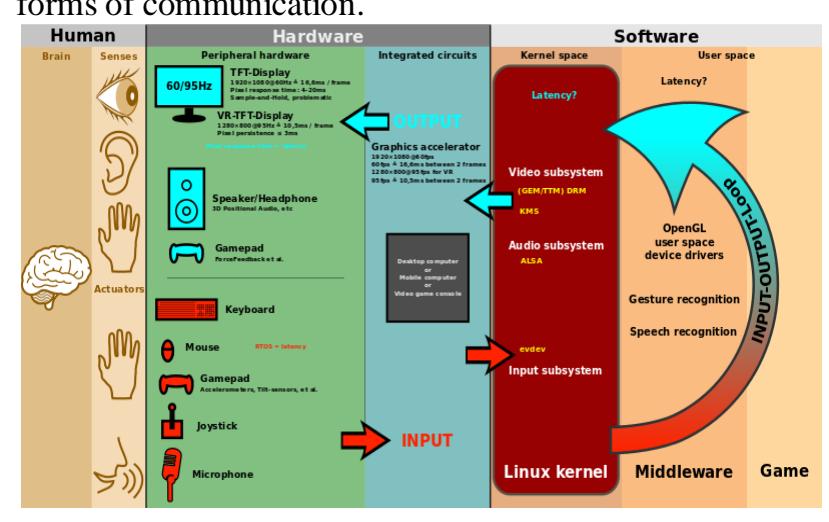

Figure 1

\section{THEORETICAL BASIS OF HUMAN-COMPUTER INTERACTION}

Human-computer interaction is based on constructivist learning and independent learning theories. Constructivism refers to the idea that learners construct knowledge for themselves---each learner individually (and socially) constructs meaning---as he or she learns. The essential core of constructivism is that learners actively construct their own knowledge and meaning from their experiences [7]. Learning is not only a knowledge acquisition process but also a constant process of self-enrichment and construction. Learning is an active process, in which the 
learner uses sensory input and constructs meaning out of it. The more traditional formulation of this idea involves the terminology of the active learner stressing that the learner needs to do something; that learning is not the passive acceptance of knowledge which exists "out there" but that learning involves the learner s engaging with the world[8]. Constructivism emphasizes learner-centeredness.

Independent learning is to make students learn how to learn. They take more responsibility for their own learning, learning on their own. They are capable of self-directed study, becoming the autonomous and long-life learners. In the process of independent learning, individuals take the initiative, with or without the help of others, in diagnosing their learning needs, formulating learning goals, identifying human and material resources for learning, choosing and implementing appropriate learning strategies, and evaluating learning outcomes.[9]Thomas Friedman said: "The world is flat. The more we push out the boundaries of knowledge and technology...the more those with the ability to learn how to learn, will be in demand.“

\section{STATUS QUO OF COLLEGE FOREIGN LANGUAGE INSTRUCTION}

Firstly, there exists unbalanced development of foreign language teaching in the colleges and universities in China nowadays. Foreign language teaching has become a difficult part of the higher education. Due to the unbalanced economic and cultural development in different regions, the problem of unbalanced development of education is very serious in the country. When students get into university, some of them with weak skills in learning foreign languages cannot read and write, but some are good at learning foreign languages. There is a substantial gap in student achievement between the urban and rural students. There is still achievement gap between students in the city. The problem of unbalanced development of foreign language teaching is very serious in the country. Owing to the strong increase in student enrollments in the recent years, more and more students with a lower level of foreign languages enrolled in regular post-secondary institutions. Some of them have lost confidence in learning foreign languages because they never got good grades in high school. The negative school experiences squelched their motivation. They lack the necessary knowledge of foreign language structure or even they can' t speak them correctly. They become so shy that they are afraid to open their mouths in foreign language class. Gradually, they lost interest in them completely. Furthermore, institutions of higher education in China differ from each other in terms of teaching resources and teacher skills. Different teaching models and approaches lead to different results. So, the proficiency and capacity in foreign languages that students attain in different colleges and universities are different.

Secondly, the existing unitary teacher-centered pattern of foreign language teaching is still popular in institutions now, in which knowledge of the language and skills is imparted only by the teacher in class. Foreign language teachers just present knowledge that they carefully prepared before class and at the same time supervise the learning process. Students sit up straight and focus on what the teachers is saying. They are passive to receive and retain knowledge imparted by their teachers and textbooks.
Students only engage in mechanical memorization, lacking the chance to practice what they learned in the foreign language class and the opportunity to use the target language in a real environment.

Thirdly, traditional lecture-based instruction and concepts are still dominant in the foreign language classrooms. Foreign language teachers still follow the centuries-old tradition "teaching for examination and learning for examination" in China of rather than the concept of quality-oriented education [10]. With the development of society and the requirements of improving the quality of students, the quality-oriented education develops in china. However, the quality-oriented education is not implemented comprehensively. In most colleges and universities, foreign language teachers are influenced by the graded standardized College English Test (Bands One to Six) [11]. The main aim of foreign language teaching is to provide students with a firm knowledge base of grammar and vocabulary. In order to pass the standardized foreign language proficiency tests, students are so eager to acquire a large vocabulary and a sophisticated knowledge of foreign languages that they hurl themselves into comprehensive reading. It is reasonable to conclude that they lack the necessary language skills, especially listening and speaking, to engage in effective communication. When they come upon the stage, they can't communicate with foreigners at work.

The alarm bells should be ringing in an academically successful school where children leave with a raft of topnotch grades. At the beginning of the 21th century, Higher education in China reaches a new seedtime, developing from elite higher education to mass higher education. Training practical personnel is an inevitable trend that is in line with market demand, fitting in with the needs of the society. Nowadays some teachers have changed the teaching methodology and explored the human-computer interaction-based instruction and applied in the foreign language teaching.

\section{FEASIBILITY OF HUMAN-COMPUTER INTERACTION- BASED FOREIGN LANGUAGE INSTRUCTION}

Since the 1970s, language laboratories have been used as an aid in foreign language teaching, which have been built in colleges and universities in China [12]. The language laboratory is a classroom where students use devices to listen and speak languages. It is an ideal place in which students learning a foreign language can practice sound and word patterns individually or under supervision with the aid of audio equipment, for example, tape recorders, video cassette recorders, or computers connected to monitoring devices enabling the instructor to listen and speak to the students individually or as a group [13]. Nowadays, more and more institutions have invested in more language labs that were designed much more modern and expensive than before in recent years and that provide more students with more opportunities to study foreign languages very conveniently.

With an increasing popularization of networking, students and teachers can play, interrogate, record and assess audio, video, text languages resources from anywhere and at anytime using a new online language lab via a web browser using a new online language lab program called SANSSpace [14]. It follows that the 
development of science and technology makes humancomputer interaction-based foreign language instruction more usable.

Since 2006, American educator, Salman Khan, has founded the Khan Academy, micro lectures are in the making in higher education in China. In 2008, two Canada scholars, George Siemens and Stephen Downes introduced a new course into the curriculum, that is, Connectivism and Connective Knowledge Online Course, hence the MOOCs, namely Massively Open Online Courses [15]. In 2011, a tenured Stanford professor, Sebastian Thrun, and his colleagues created an online course called Introduction to Artificial Intelligence. Since then, the interest surrounding the use of MOOCs has continued to grow in China. Micro lectures and MOOCs are the now forms of human-computer interaction. Foreign language teachers in the colleges and universities take advantage of micro lectures and MOOCs to get much more excellent results in second language teaching.

\section{ELABORATION OF HUMAN-COMPUTER INTERACTION-BASED FOREIGN LANGUAGE TEACHING MODEL}

The ideal human-computer interaction-based foreign language teaching model can create real-life situations for teachers and students, which help students to get best learning effect. The foreign language teacher has a computer with appropriate software for conducting language exercises. Text, images, audio and video can easily be integrated and teachers can alter materials to fit their requirements [16]. Foreign language speaking situations and conversation practice for students are made based on real foreign language content and meaningful communication. Students learn to communicate in real life situations in foreign language. With the situations necessary to survive in a foreign language-speaking environment, students are in a position to make even better use of the language they are learning. Using the language in a real context can elicit their motivations and interests of foreign languages.

The human-computer interaction-based foreign language teaching model can improve students , autonomous learning ability. The content of teaching materials was designed professionally and reasonably, offering the choices for users to study in their own preferred setting, location or facilities. Students can choose their own studying pattern to complement their level of knowledge [17], using self-paced learning. Students are allowed more control over their own learning process as they make the decisions when to repeat questions, exercises and sequences based on their own progress. For example, in the field of pronunciation, students can employ a computer to record themselves to compare their pronunciation to a target pronunciation. This can be repeated endlessly until a student is satisfied with his/her result. These pronunciation exercises are often combined with visual aids (such as intonation graphs) to help the student recognize how his/her pronunciation compares to the target pronunciation [18].

In the learning process, students can not only repeat the words, sentences or conversations that they have heard, but ask questions, answer questions and receive timely feedback on what they did and guidance from their teachers in time. Feedback is critical to improving performance. Providing feedback can reinforce what has been learned and can also correct any misconceptions [19]. Multimedia provides a complex multi-sensory experience in exploring the world through the presentation of information through text, graphics, images, audio and video [20].

\section{ADVANTAGES OF HUMAN-COMPUTER}

\section{INTERACTION-BASED FOREIGN LANGUAGE TEACHING} MODEL

The colorful human-machine interface is conducive to stimulating students, interest in learning, improving students' understanding of knowledge and strengthening students' memories. Albert Einstein once said: "Interest is the best teacher." Network environment provides an interactive space to teachers and students, which makes students interested in learning. Meanwhile, students' negative attitudes were changed to positive attitudes and curiosity toward studying foreign languages. Humancomputer interaction-based foreign language teaching model helps students improve self-confidence in learning and improve the students' ability to apply the basic knowledge.

Multimedia software and the network environment provide students with a variety of learning materials that meet the different learning needs and different learning abilities of students. Students can select the learning content that is suitable for their needs. Asynchronous learning has closed the gaps between underachievers and top students and improved their learning abilities as a whole. Although students have different levels of motivation, different attitudes about teaching and learning, and different responses to specific learning environments, all of them get improved access to skills and knowledge.

When students study in the human-computer interaction-based teaching environment, they aren' $t$ scared of making any mistakes and don' t feel nervous, embarrassed, or tongue-tied any longer. They feel more secure and less anxious, which can promote students' healthy physical and mental development and form healthy personality. Daniel Goleman (1996) once said, "Emotional intelligence is a master aptitude that profoundly affects all other abilities. By developing your Emotional Intelligence you will be both happy and successful at whatever you do. The human-computer interaction-based teaching environment provides students a good chance to develop their Emotional Intelligence.

\section{CONCLUSIONS}

Human-computer interaction-based foreign language instruction is based on learner-centered, interactive and teacher-led teaching model, creating real-life foreign language situations in the classroom with computers. Students learn foreign languages in a very easy and convenient manner. They select, manage, and assess their own learning activities, which contributes to personality development and cultivating practical abilities. Humancomputer interaction-based teaching increases student contact time with foreign languages and provides more opportunities for students to use language, mobilizing students' learning enthusiasm [21]. Meanwhile, it is the 
best way to bring about excellent results in second language teaching. Human-computer interaction-based foreign language instruction will occupy an important position in the higher education in the near future. With development of Information Technology, especially the development of multimedia technology, the days of spoonfeeding for exam results have got to be numbered and a new era in the history of teaching has come.

\section{REFERENCES}

[1] Lai-Mei Leong. EFL Teachers' Attitudes toward Using Computer Technology in English Language Teaching. Theory and Practice in Language Studies, Vol. 2, No. 3, pp. 630-636, March 2012.

[2] Ya-Ling Wu, Wen-Ming Wu, Chaang-Yung Kung and Ming-Yuan Hsieh. The Effect of Web-based Instruction on English Writing for College Students. Intelligent Decision Technologies, Smart Innovation, Systems and Technologies, Volume 10, 2011, pp 597604.

[3] http://dxwyb.jnxy.edu.cn/onews.asp?id=140\&Page=1.

[4] Elizabeth Churchill, Anne Bowser, Jennifer Preece. Teaching and Learning Human-computer Interaction. Interactions, March/April 2013, pp 44. http://interactions.acm.org/archive/view/march-april2013/teaching-and-learning-human-computer-interaction.

[5] P. Johnson. Human computer interaction: Psychology, task analysis, and software engineering. London: McGraw-Hill, 1992.

[6] http://www.waset.org/journals/waset/v52/v52-90.pdf.

[7] Peter, E.D., William, G.C.. Constructivism: The career and teaching education perspective.
[8] Fromhttp://vcampus.uom.av.mu/uoload/private/200332695533/200 332695533.pdf.

[9] J. Dewey. Democracy and Education [M]. 1st ed. [S.1.] MacMillan, 1916.

[10] Knowles. Selfdirected learning: a guide for learners and teachers[M]. Chicago: Follett Publishing Company, 1975.

[11] http://www.china.org.cn/english/zhuanti/china2003/73356.htm.

[12] http://www.nie.edu.sg/nie_cma/attachments/topic/147e7c6cb6ZG/ Silver_Monograph.pdf.

[13] Liu Jinging. The Talk-to-Machine Method used in Teaching Speaking English in College. MIFLI, No.83, Feb. 2002.

[14] http://www.yourdictionary.com/language-laboratory.

[15] http://www.connectededucation.com/2012/09/bring-your-ownlanguage-lab.

[16] Wei Ying. Research on the coping measures of traditional higher education in the MOOCs Era[J]. Journal of The Chinese Society of Education, 2014(S3).

[17] http://www.sanako.com/what-is-language-lab.

[18] Heller, M.. Linguistic Minorities and Modernity: A Sociolinguistic Ethnography. London: Longman, 2005.

[19] http://esl.about.com/od/esleflteachingtechnique/a/t_compclass.htm.

[20] J. P. Gee. Learning by design: Good video games as learning machines. E-Learning(2), pp 5-16, 2005.

[21] R. E. Mayer. Multimedia learning. New York: Cambridge University Press, 2001.

[22] J. P. Gee. Learning by design: Good video games as learning machines. E-Learning (2), pp 5-16, 2005. 